\title{
Identification of Angiogenic Cargo in Extracellular Vesicles Secreted from Human Adipose Tissue-Derived Stem Cells and Induction of Angiogenesis In Vitro and In Vivo
}

\author{
Prakash Gangadaran ${ }^{1,2, \dagger}$, Ramya Lakshmi Rajendran ${ }^{2,+}$, Ji Min $\mathrm{Oh}^{2}$, Eun Jung $\mathrm{Oh}^{3} \oplus$, Chae Moon Hong ${ }^{4}($, \\ Ho Yun Chung ${ }^{1,3}$, Jaetae Lee ${ }^{2,4}$ and Byeong-Cheol Ahn $1,2,4, *$ (D)
}

1 BK21 FOUR KNU Convergence Educational Program of Biomedical Sciences for Creative Future Talents, Department of Biomedical Sciences, School of Medicine, Kyungpook National University, Daegu 41944, Korea; prakashg@knu.ac.kr (P.G.); hy-chung@knu.ac.kr (H.Y.C.)

2 Department of Nuclear Medicine, School of Medicine, Kyungpook National University, Daegu 41944, Korea; ramyag@knu.ac.kr (R.L.R.); ojm0366@knu.ac.kr (J.M.O.); jaetae@knu.ac.kr (J.L.)

3 Department of Plastic and Reconstructive Surgery, CMRI, School of Medicine, Kyungpook National

University Hospital, Kyungpook National University, Daegu 41944, Korea; fullrest74@knu.ac.kr

4 Department of Nuclear Medicine, School of Medicine, Kyungpook National University Hospital, Kyungpook National University, 680 Gukchaebosangro, Junggu, Daegu 41944, Korea; cmhong@knu.ac.kr

* Correspondence: abc2000@knu.ac.kr; Tel.: +82-53-420-5583; Fax: +82-53-200-6447

+ Co-first author.

\section{check for} updates

Citation: Gangadaran, P.; Rajendran, R.L.; Oh, J.M.; Oh, E.J.; Hong, C.M.;

Chung, H.Y.; Lee, J.; Ahn, B.-C. Identification of Angiogenic Cargo in Extracellular Vesicles Secreted from Human Adipose Tissue-Derived Stem Cells and Induction of Angiogenesis In Vitro and In Vivo. Pharmaceutics 2021, 13, 495. https://doi.org/ 10.3390/pharmaceutics13040495

Academic Editor: Santosh Aryal

Received: 11 March 2021

Accepted: 29 March 2021

Published: 5 April 2021

Publisher's Note: MDPI stays neutral with regard to jurisdictional claims in published maps and institutional affiliations.

Copyright: (c) 2021 by the authors. Licensee MDPI, Basel, Switzerland. This article is an open access article distributed under the terms and conditions of the Creative Commons Attribution (CC BY) license (https:// creativecommons.org/licenses/by/ $4.0 /)$.

\begin{abstract}
Angiogenesis is defined as the generation of new blood vessels or the sprouting of endothelial cells from a pre-existing vascular network. Angiogenesis occurs during the growth and development of an organism, the response of organs or tissues to injury, and during cancer development and progression. The majority of studies on stem-cell-derived extracellular vesicles (EVs) have used cell lines, and have primarily focused on well-known solitary proteins. Here, we isolated stem cells from human adipose tissue (ADSCs), and we isolated EVs from them (ADSC-EVs). The ADSCEVs were characterised and 20 angiogenic proteins were analysed using an angiogenic antibody array. Furthermore, we analysed the ability of ADSC-EVs to induce angiogenesis in vitro and in vivo. ADSC-EVs were positive for CD81 and negative for GM130, calnexin, and cytochrome-C. ADSC-EVs showed typical EV spherical morphology and were $200 \mathrm{~nm}$ in size. ADSC-EVs were found to contain angiogenic proteins as cargo, among which interleukin 8 (IL-8) was the most abundant, followed by chemokine (C-C motif) ligand 2 (CCL2), a tissue inhibitor of metalloproteinases 1 (TIMP-1), TIMP-2, and vascular endothelial growth factor-D (VEGF-D). ADSC-EVs treatment increased the proliferation, migration, total vessel length, total number of junctions, and junction density of endothelial cells in vitro. The results of an in vivo Matrigel plug assay revealed that ADSC-EVs induced more blood vessels in the Matrigel compared with the control. These results demonstrate that ADSC-EVs contain angiogenic proteins as cargo and promote angiogenesis in vitro and in vivo. Therefore, ADSC-EVs have potential for therapeutic use in ischaemia.
\end{abstract}

Keywords: adipose tissue; stem cell; extracellular vesicle; angiogenesis

\section{Introduction}

Angiogenesis is described as the generation of new blood vessels or the sprouting of endothelial cells from a pre-existing vascular network. Angiogenesis occurs naturally during the growth and development of an organism. Ischaemia, a restriction in blood supply to tissues, deprives cells and tissues of oxygen, which is required for cellular metabolism [1]. Angiogenesis also occurs during the response to ischaemia, to restore blood supply to the ischaemic tissues [2]. Blood vessel growth is initiated by an imbalance in the expression of angiogenic factors as a result of pathological conditions [3-5]. Ischaemic diseases are some of the deadliest, and account for millions of deaths worldwide [6,7]. 
Therefore, the development of novel therapeutic strategies for the treatment of ischaemic diseases is urgently needed.

Many preclinical and clinical studies have reported therapeutic effects of stem cells in ischaemic brain injury, ischaemic heart failure, and limb ischaemia [8-13]. Although stem cell therapies have been shown to have numerous advantages over conventional therapies, their feasible translation is hindered by many factors, including the isolation of stem cells (especially stem cells derived from the bone marrow, embryo, and umbilical cord), the inability to control differentiation after administration, immunological rejection, tumour formation, inappropriate stem cell migration, the viability of cells after administration, and the limited understanding of how stem cells work in vivo [14-19]. Therefore, it is important to develop other therapeutic approaches to accelerate angiogenesis in ischaemia with no or minimal adverse effects.

It has recently been accepted that the therapeutic effects of many cells, including stem cells, occur primarily through the secretion of paracrine factors, including extracellular vesicles (EVs) [20-24]. EVs are nano-sized vesicles secreted by almost all cells, and consist of exosomes and small EVs (30-200 nm), as well as micro-vesicles $(30-500 \mathrm{~nm})$. EVs are capable of carrying functionally active biological materials such as lipids, proteins, mRNAs, miRNAs, and DNAs, and delivering them to recipient cells $[25,26]$. Given their biological properties, the exploitation of EVs as therapeutic agents is a primary research focus.

Numerous studies have recently shown that EVs derived from mesenchymal stem cells (MSC-EVs) are capable of inducing angiogenesis in the context of ischaemic diseases and wound healing $[20,23,24,27-31]$. However, most of these previous studies used EVs derived from either cell lines or bone marrow stem cells, while others used EVs derived from umbilical cord stem cells. However, few studies have isolated EVs from primary human adipose tissue-derived stem cells (ADSCs) to investigate their angiogenic potential [32]. ADSCs are easily and readily isolated from adipose tissues that are discarded during liposuction procedures or other surgeries; however, bone marrow stem cells are not readily available, and isolation requires complex procedures [33,34]. The most important consideration in $\mathrm{EV}$ isolation is the number of cells required to produce a sufficiently large number of EVs to be used clinically or for exclusive personalised therapies (autologous or allogeneic). Previous studies have reported that stem cells isolated from adipose tissues give rise to 500 times more cells compared with those from bone marrow aspirates $[34,35]$.

Here, we isolated ADSC-EVs from ADSCs harvested from human tissues to examine the presence of angiogenic protein cargo in ADSC-EVs, and to investigate the angiogenic effects of ADSC-EVs both in vitro and in vivo.

\section{Materials and Methods}

\subsection{Collection of ADSCs and Cell Culture}

Adipose tissues were obtained from discarded subcutaneous tissue during flap surgery, as described previously [36]. ADSCs and SVEC-4 (mouse endothelial cell line) were cultured in DMEM (Gibco, Carlsbad, CA, USA) supplemented with 10\% foetal bovine serum (FBS; Hyclone, Logan, UT, USA). Both cell types were supplemented with $10 \%$ EV-depleted FBS (the FBS was ultracentrifuged for $18 \mathrm{~h}$ at $120,000 \times \mathrm{g}$ at $4{ }^{\circ} \mathrm{C}$ ) and $1 \%$ penicillin and streptomycin, in a $\mathrm{CO}_{2}$ incubator at $37^{\circ} \mathrm{C}$.

\subsection{Isolation of EVs}

ADSC cultured media (up to five passages) were collected and EVs were isolated as illustrated in Figure 1A. The supernatants were briefly centrifuged for $10 \mathrm{~min}$ at $1500 \times g$ to remove the cells, and then for $20 \mathrm{~min}$ at $4000 \times g$ to remove the cell debris. The collected supernatant was filtered through a $0.45 \mu \mathrm{m}$ syringe. The samples were ultracentrifuged for $60 \mathrm{~min}$ at $100,000 \times g$ The collected pellets were washed with phosphate-buffered saline (PBS) and again ultracentrifuged for $60 \mathrm{~min}$ at $100,000 \times g$ The pellets were reconstituted in 50-100 $\mu \mathrm{L}$ PBS and stored at $-80{ }^{\circ} \mathrm{C}$ until use. All ultracentrifugation procedures were performed using a SW28 rotor at $4{ }^{\circ} \mathrm{C}$ (Beckman Coulter, Brea, CA, USA). The 
concentration of EVs was measured with a Pierce BCA Protein Assay Kit (Thermo Fisher Scientific, Waltham, MA, USA).

A

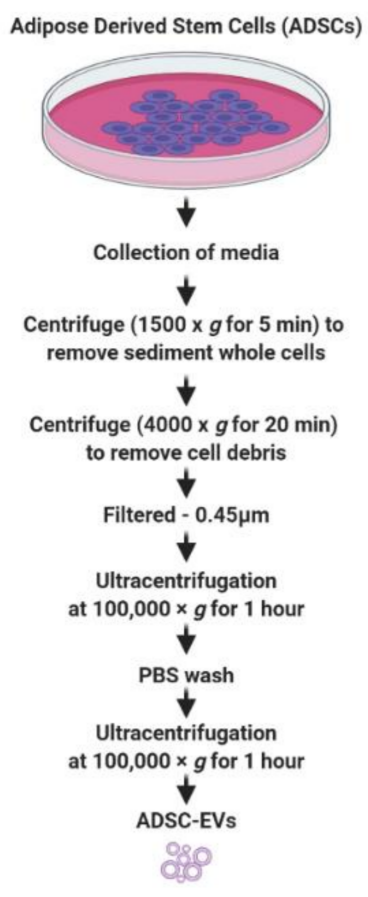

B

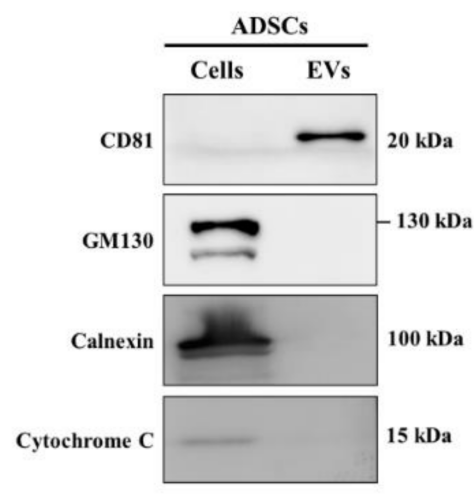

C

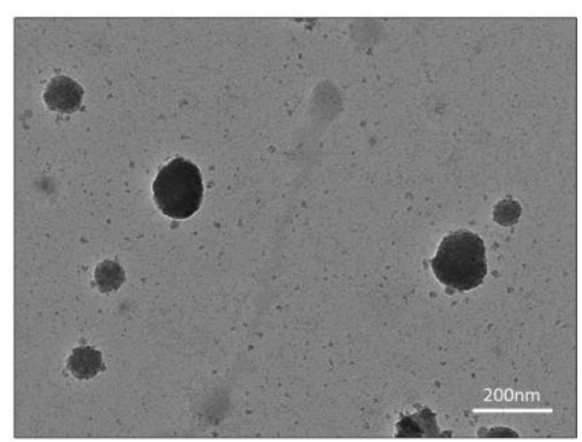

D

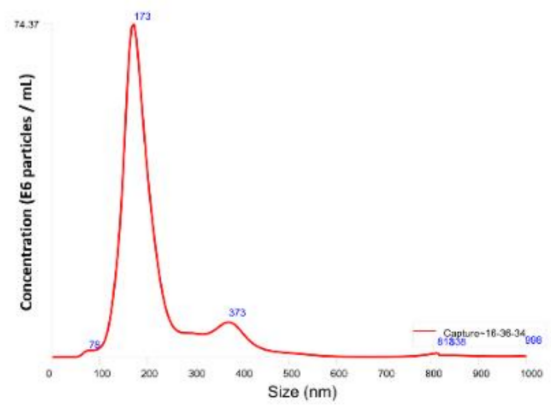

$\mathbf{E}$

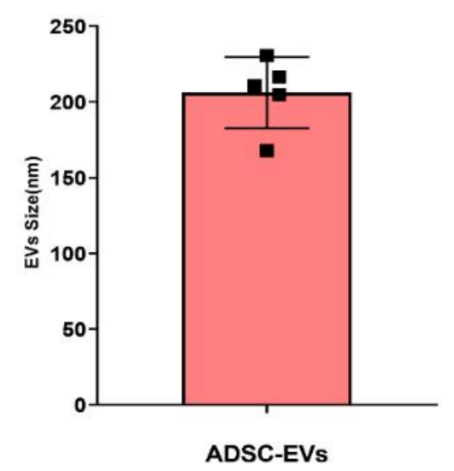

Figure 1. Isolation and characterisation of adipose tissue-derived stem cell extracellular vesicles (ADSC-EVs). (A) A schematic diagram demonstrating the isolation of EVs from ADSCs (created with BioRender.com). (B) Western blot analysis of ADSCs (cells and EVs); anti-CD81, anti-GM130, calnexin, and anti-cytochrome-C antibodies were used. (C) The morphology of ADSC-EVs visualised by TEM (scale bar: $200 \mathrm{~nm})$. (D,E) NTA of ADSC-EVs $(n=5)$. The results are expressed as the mean $\pm \mathrm{SD}$ values of the experiment.

\subsection{Western Blotting}

Western blot analysis was performed as described in a previous study [22]. ADSC and ADSC-EVs lysates were prepared in RIPA buffer (Thermo Fisher Scientific, Waltham, MA, USA). Equal amounts of protein were loaded and separated using 10\% SDS-polyacrylamide gel electrophoresis. The proteins were transferred to PVDF membranes (Millipore, Burlington, MA, USA). The blots were first probed with the primary antibody (CD81 (1:2500), Alix (1:2500), and cytochrome-C (1:5000); all Abcam), and then with the secondary antibody conjugated with horseradish peroxidase (Cell Signalling Technology, Danvers, MA, USA). The signals were detected using enhanced chemiluminescence (GE Healthcare, Chicago, IL, USA) according to the manufacturer's instructions.

\subsection{Transmission Electron Microscopy (TEM)}

The ADSC-EVs were resuspended in $2 \%$ paraformaldehyde $(100 \mu \mathrm{L})$. ADSC-EVs pellets were attached to Formvar/carbon-coated EM grids. To avoid exposure to light, the sample was covered with aluminium foil for $20 \mathrm{~min}$ to avoid any damage/dryness to the sample. The sample was washed with $100 \mu \mathrm{L}$ PBS and incubated in $1 \%$ of glutaraldehyde for $5 \mathrm{~min}$. The sample was washed with distilled water seven times ( 2 min each) and viewed under HT 7700 TEM to observe the size of the ADSC-EVs [20]. 


\subsection{Nanoparticle Tracking Analysis (NTA)}

The size of the ADSC-EVs was determined by NTA using a NanoSight LM10 (Malvern) with a $640 \mathrm{~nm}$ laser according to the described protocol. ADSC-EVs were briefly diluted in Milli-Q water (1:1000) and the sample was injected into the chamber using a sterile syringe. The measurements were performed and the average of the results was recorded [20].

\subsection{Human Angiogenesis Array}

Proteins extracted from ADSC-EVs (150 $\mu \mathrm{g} / \mathrm{blot})$ of two human subjects were used for this assay. The Human Angiogenesis Array (RayBiotech, Peachtree Corners, GA, USA) was used according to the manufacturer's instructions. The intensity was measured by GelQuant.NET software (Version 1.8.2) (BiochemLabSolutions.com, San Francisco, CA, USA).

\subsection{EV Labelling and Internalisation Assay}

The internalisation of ADSC-EVs was analysed by confocal microscopy. The EVs were labelled with lipophilic dye (DiD) by incubating for $20 \mathrm{~min}$ at $37^{\circ} \mathrm{C}$ and washing with PBS by ultracentrifugation, as mentioned above. The DiD-labelled ADSC-EVs $(5$ or $10 \mu \mathrm{g} / \mathrm{mL})$ or unlabelled ADSC-EVs ( 5 or $10 \mu \mathrm{g} / \mathrm{mL}$ ) were incubated with endothelial cells for $2 \mathrm{~h}$ at $37^{\circ} \mathrm{C}$ before methanol fixation. Antifade agent was used to mount the coverslips (Vector Laboratories, Burlingame, CA, USA). The uptake of ADSC-EVs was observed by LSM 800 laser scanning microscopy (Carl Zeiss, Baden-Württemberg, Germany).

\subsection{In Vitro Transwell Migration Assay}

First, $600 \mu \mathrm{L}$ of medium with $3 \%$ FBS was added into the lower chamber of a 24-well plate. Then, endothelial cells $\left(1.5 \times 10^{4}\right)$ in $300 \mu \mathrm{L}$ medium $(0 \%$ FBS $)$ was added onto the transwell membrane insert. Immediately, ADSC-EVs $(5$ and $10 \mu \mathrm{g} / \mathrm{mL})$ were added onto the top of the insert and incubated for $24 \mathrm{~h}$ in a $\mathrm{CO}_{2}$ incubator. The cells were fixed and stained with crystal violet as previously described [37]. The cells were visualised and imaged with an AXIO microscope (Zeiss, Baden-Württemberg, Oberkochen, Germany).

\subsection{In Vitro Cellular Proliferation Assay}

Endothelial cells were seeded at $1 \times 10^{4}$ cells/well in $100 \mu \mathrm{L}$ of medium in a 96-well plate, and incubated in a $\mathrm{CO}_{2}$ incubator overnight. Then, the cells were treated with 0 , $5,10,15$, or $20 \mu \mathrm{g} / \mathrm{mL}$ of ADSC-EVs for $24 \mathrm{~h}$. Cellular proliferation was assessed by the optical density at a $450 \mathrm{~nm}$ wavelength using a spectrophotometer, according to the manufacturer's protocol (CCK8 assay kit, Dojindo Molecular Technologies, Kyushu, Japan), and the results are presented as percentages.

\subsection{In Vitro Matrigel Tube Formation Assay}

Matrigel Growth Factor Reduced Basement Membrane Matrix (Conc: 100\%) (Matrigel; Corning) was coated onto 24 -well culture plates followed by incubation at $37^{\circ} \mathrm{C}$ for $1 \mathrm{~h}$ to allow the gel to settle. Then, $2 \times 10^{4}$ endothelial cells/well were added into the plates followed by ADSC-EVs ( 5 and $10 \mu \mathrm{g} / \mathrm{mL}$ ). After $4 \mathrm{~h}$, the cells were visualised and imaged (four images/group) with fluorescence microscopy (AXIO, Zeiss, Oberkochen, Germany). The total vessel length, number of junctions, and density of junctions were counted/measured automatically $(n=4)$ by AngioTool64 software (National Cancer Institute, Radiation Oncology Branch, Angiogenesis Core Facility, Maryland, MD, USA) [38].

\subsection{In Vivo Matrigel Plug Assay in Mice}

The mice $(n=7)$ were anaesthetised, and the following mixture was subcutaneously injected into the right lower flank. The Matrigel-only group mice $(n=3)$ were administered $300 \mu \mathrm{L}$ Matrigel (Conc. 100\%) and the Matrigel + ADSC-EVs group mice $(n=4)$ were administered $300 \mu \mathrm{L}$ Matrigel (Conc. 100\%) +50 $\mu$ g ADSC-EVs. The Matrigel plugs were 
removed after 2 weeks, and the images were captured using a surgical microscope (M320 F12; Leica Microsystems, Germany).

\subsection{Histology and Microscopy}

The Matrigel plugs were fixed immediately after imaging in $10 \%$ neutral buffered formalin, embedded in paraffin, and sectioned at 3-4 $\mu \mathrm{m}$. The sections were stained with haematoxylin and eosin (H\&E) [8]. The H\&E slide sections were imaged under an AXIO microscope (Zeiss, Oberkochen, Germany). The number of blood vessels per image or plug was counted.

\subsection{Statistical Analysis}

All data are expressed as the mean \pm standard deviation (SD). Two groups of data were analysed by Student's $t$-test in MS Office Excel sheet (Microsoft, Redmond, WA, USA) or GraphPad Prism 9 software version 9.0.0 (GraphPad Software, Inc., San Diego, CA, USA). A $p$-value $<0.05$ was considered statistically significant.

\section{Results}

\subsection{Characterisation of ADSC-EVS}

The primary ADSC cultured media was collected and used for the isolation and purification of ADSC-EVs by ultracentrifugation, as illustrated in Figure 1A. The enrichment and purity of EVs were confirmed by the well-characterised positive and negative markers of ADSC-EVs. Western blotting results showed an enrichment of CD81 (a membrane protein) in the ADSC-EVs fraction compared with the source cells; whereas the negative markers, GM130 (Golgi apparatus), calnexin (endoplasmic reticulum), and cytochrome-C (mitochondria), were only present in the cells (Figure 1B). These results confirmed that ADSC-EVs isolated from ADSCs were intact and without cellular contamination. The morphology of ADSC-EVs was observed by TEM, which revealed that the EVs had a typical spherical morphology and were mostly intact (Figure 1C). The size of the ADSC-EVs was confirmed by NTA, which revealed a single enriched peak at $178 \mathrm{~nm}$ and an average diameter of $206.2 \pm 23.5 \mathrm{~nm}$ (Figure 1D,E). These results suggest that ADSC-EVs were successfully isolated from human primary ADSCs.

\subsection{Angiogenic Protein Cargo in Human ADSC-EVs}

Twenty angiogenic proteins in the EVs isolated from ADSCs were analysed by angiogenic array (Figure 2A). The results revealed that interleukin 8 (IL-8), also called chemokine (C-X-C motif) ligand 8 (CXCL8), was present in ADSC-EVs at a higher concentration than the other proteins, followed by chemokine (C-C motif) ligand 2 (CCL2), a tissue inhibitor of metalloproteinases 1 (TIMP-1), TIMP-2, and vascular endothelial growth factor-D (VEGF-D) (Figure 2B,C). Growth-regulated oncogene alpha/beta/gamma (GRO $\alpha / \beta / \gamma)$, basal fibroblast growth factor (bFGF), and interferon gamma (IFN- $\gamma$ ) were also present at low levels. The remaining proteins were present at low levels, and the level of platelet-derived growth factor BB was negligible (Figure 2B,C). These results clearly confirm that the ADSC-EVs were packed with various angiogenic proteins. 
A

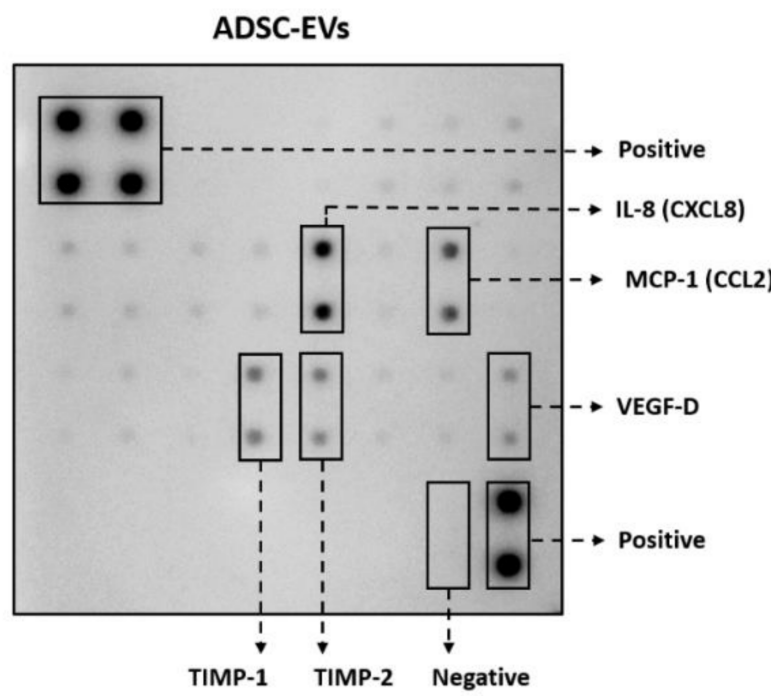

B

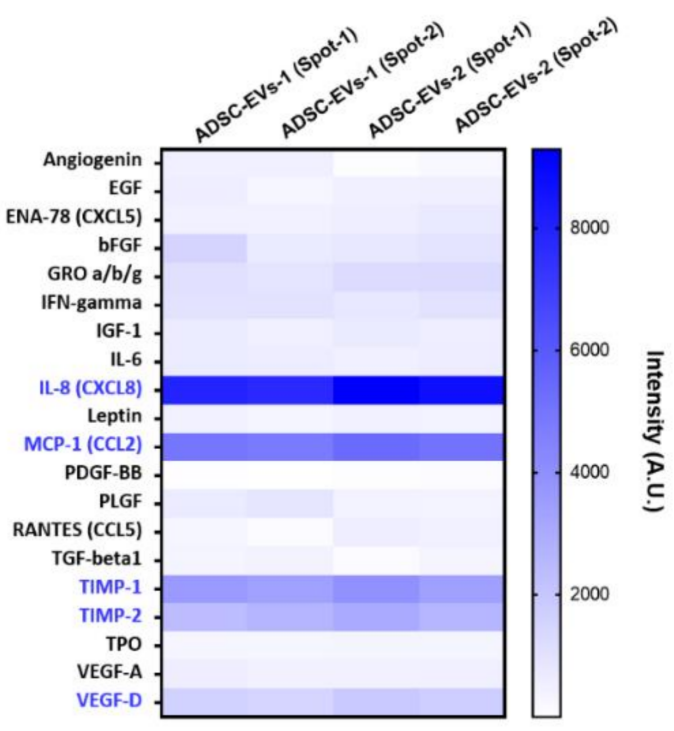

C

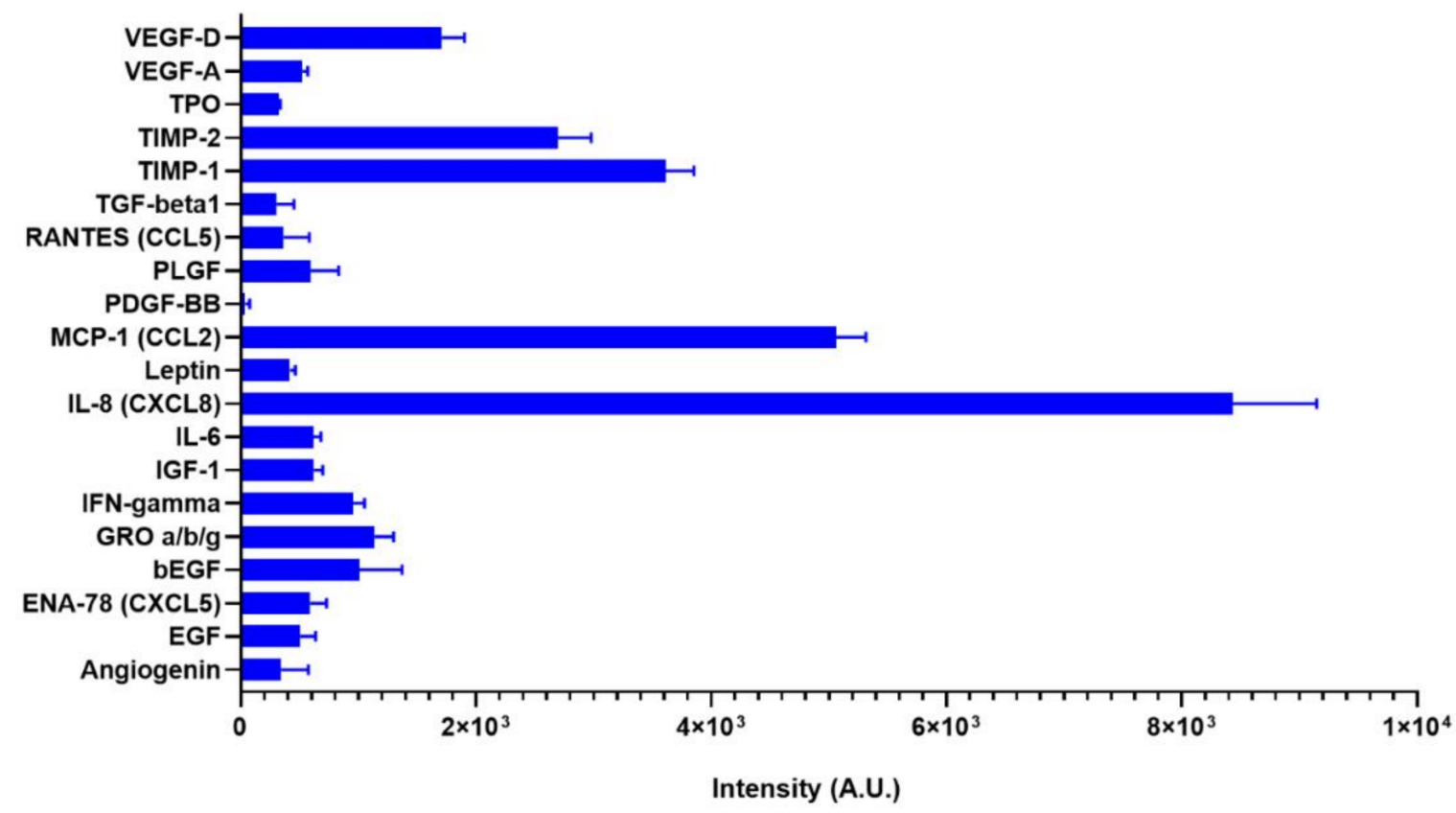

Figure 2. Angiogenic array reveals the presence of angiogenic proteins in ADSC-EVs. (A) The representative array blot incubated with ADSC-EVs lysate $(150 \mu \mathrm{g} / \mathrm{blot})$. (B) The quantitative results of the spots of each protein $(n=4)$. (C) Bar graph of the quantitative results (intensity) of the spots of each protein $(n=4)$.

\subsection{Endothelial Cell Internalisation of ADSC-EVs}

The internalisation of ADSC-EVs by endothelial cells was confirmed by fluorescence microscopy, by labelling the ADSC-EVs with lipophilic dye (DiD). The results reveal that ADSC-EVs were readily internalised by endothelial cells (Figure 3). 

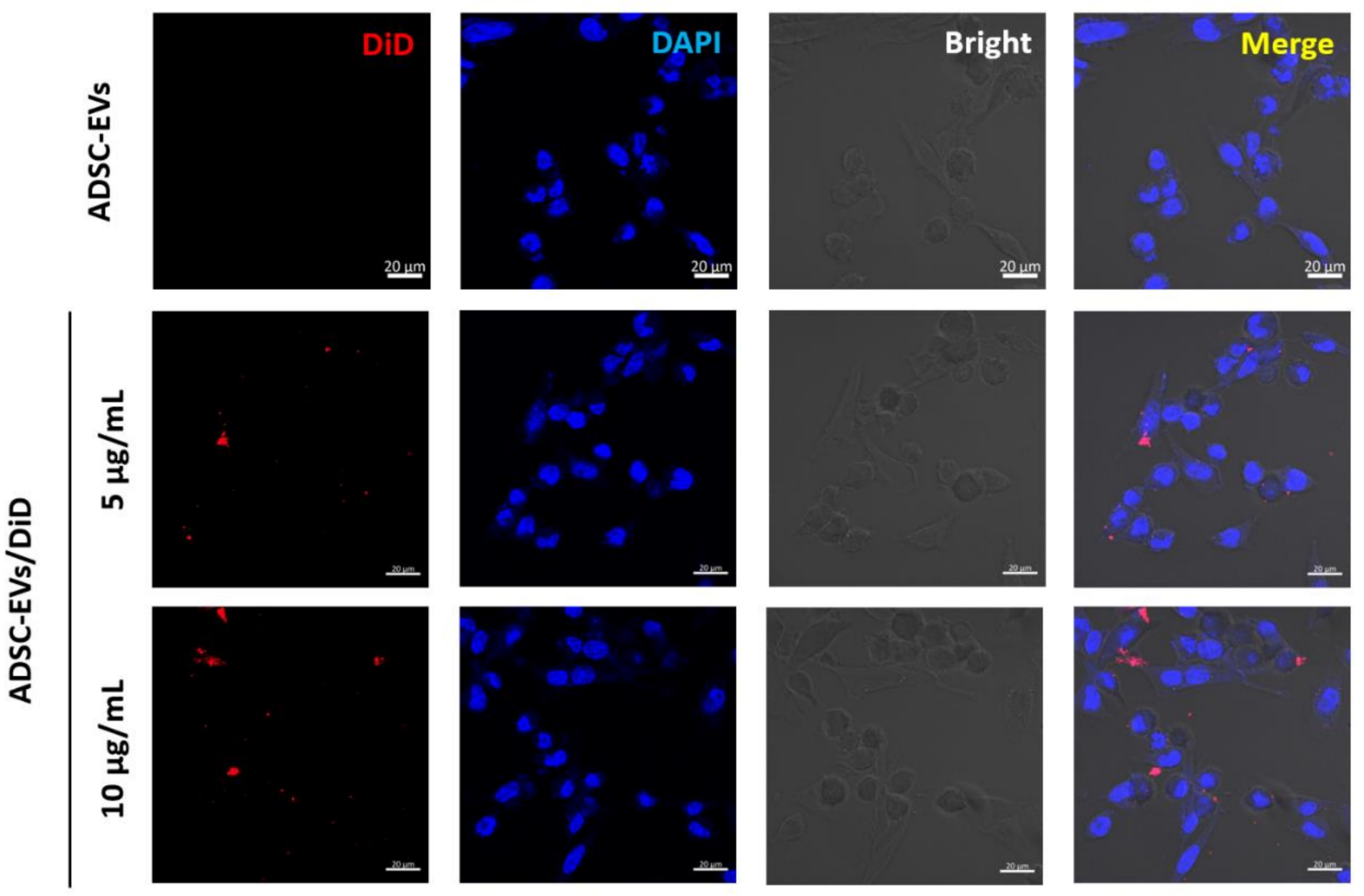

Figure 3. Endothelial cells internalised ADSC-EVs. Endothelial cells were incubated with unlabelled ADSC-EVs $(10 \mu \mathrm{g} / \mathrm{mL})$ and DiD-labelled ADSC-EVs (5 or $10 \mu \mathrm{g} / \mathrm{mL}$; ADSC-EVs/DiD) for $2 \mathrm{~h}$; arrows indicate internalised ADSC-EVs (scale bar: $20 \mu \mathrm{m})$.

\subsection{Human ADSC-EVs Promote the Migration and Proliferation of Endothelial Cells}

Angiogenesis is a complex multistep process, wherein endothelial cells migrate, proliferate, and generate new blood vessels. The ability of ADSC-EVs to induce the migration of endothelial cells was examined. The transwell migration results showed that ADSC-EVs ( 5 and $10 \mu \mathrm{g} / \mathrm{mL}$ ) were able to significantly $(p<0.001)$ increase the migration of endothelial cells, which was further increased by treatment with $10 \mu \mathrm{g} / \mathrm{mL}$ of ADSC-EVs $(p<0.05)$. Thus, endothelial cell migration was increased by ADSC-EVs in a dose-dependent manner (Figure 4A,B). Next, the ability of ADSC-EVs $(5,10,15$, and $20 \mu \mathrm{g} / \mathrm{mL}$ ) to induce the proliferation of endothelial cells was investigated. The results showed that the proliferation of endothelial cells significantly increased following treatment with ADSC-EVs $(5 \mu \mathrm{g} / \mathrm{mL}$ : $p<0.01$ and 10-20 $\mu \mathrm{g} / \mathrm{mL}: p<0.001$ ) compared with the control (Figure 4C). These results show that ADSC-EVs are capable of inducing the migration and proliferation of endothelial cells. 
A

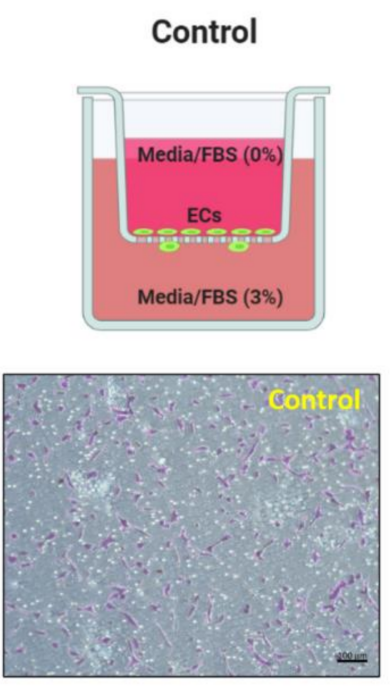

$5 \mu \mathrm{g} / \mathrm{mL}$
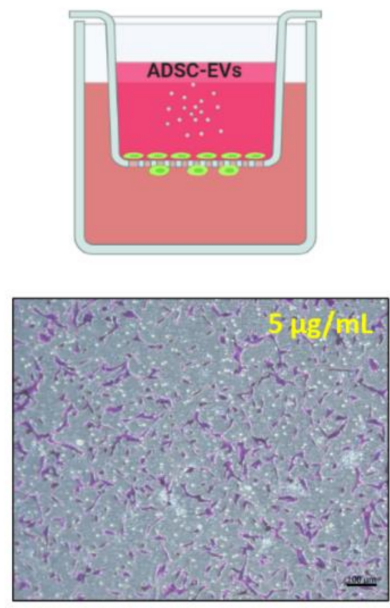

$10 \mu \mathrm{g} / \mathrm{mL}$
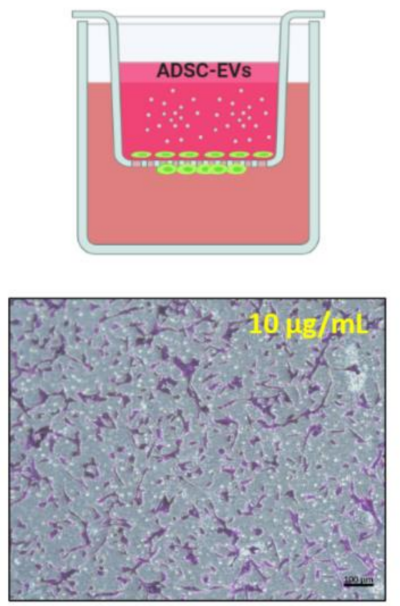

B

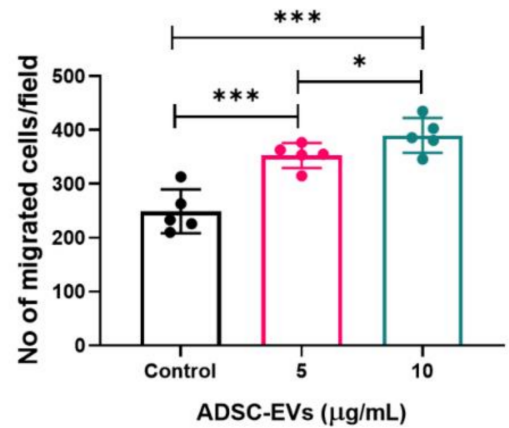

C

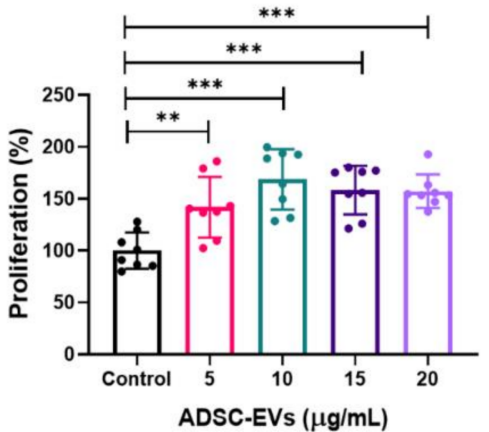

Figure 4. Increased migration and proliferation of endothelial cells by treatment with ADSC-EVs. (A) Graphical scheme of the migration assay (figure created with BioRender.com) and phase contrast microscopy images of migrated endothelial cells after $24 \mathrm{~h}$ treatment with ADSC-EVs (5 and $10 \mu \mathrm{g} / \mathrm{mL})$. (B) Quantified data of migrated cells shown in (A) $(n=5)$. (C) Graph showing the proliferation of endothelial cells quantified via CCK8 assay after $24 \mathrm{~h}$ treatment with $0-20 \mu \mathrm{g} / \mathrm{mL}$ of ADSC-EVs $(n=8) .{ }^{*} p<0.05,{ }^{* *} p<0.01,{ }^{* * *} p<0.001$ by Student's $t$-test.

\subsection{ADSC-EVs Promote Tube Formation in Endothelial Cells}

Next, we tested the capacity of endothelial cells to form blood vessels in vitro following treatment with ADSC-EVs ( 5 and $10 \mu \mathrm{g} / \mathrm{mL}$ ) for $4 \mathrm{~h}$. Following treatment, the endothelial cells were imaged with a microscope (Figure 5A) and the images were analysed by AngioTool software (National Cancer Institute, Radiation Oncology Branch, Angiogenesis Core Facility, Maryland, MD, USA). The images represent the vessel length, number of junctions, and junction density (Figure 5B; redline tube-like structure and red dot: junctions). The vessel length was substantially increased at $5 \mu \mathrm{g} / \mathrm{mL}$, and significantly increased $(p<0.001)$ at $10 \mu \mathrm{g} / \mathrm{mL}$ compared with the control (Figure 5C). The number of junctions was substantially increased at $5 \mu \mathrm{g} / \mathrm{mL}$ compared with the control, and significantly increased $(p<0.05$ and $p<0.01)$ at $10 \mu \mathrm{g} / \mathrm{mL}$ compared with $5 \mu \mathrm{g} / \mathrm{mL}$ and the control (Figure 5D). The density of the junctions was also substantially increased at $5 \mu \mathrm{g} / \mathrm{mL}$ compared with the control and significantly increased $(p<0.05$ and $p<0.01)$ at $10 \mu \mathrm{g} / \mathrm{mL}$ compared with $5 \mu \mathrm{g} / \mathrm{mL}$ and the control (Figure $5 \mathrm{E}$ ). These results confirm that ADSC-EVs are capable of inducing angiogenesis. 
A

ADSC-EVs $(\mu \mathrm{g} / \mathrm{mL})$

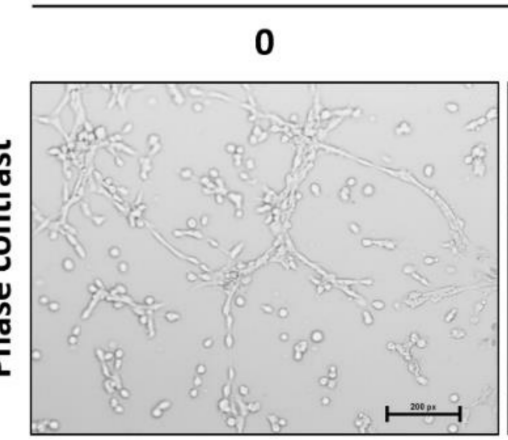

5

10

B
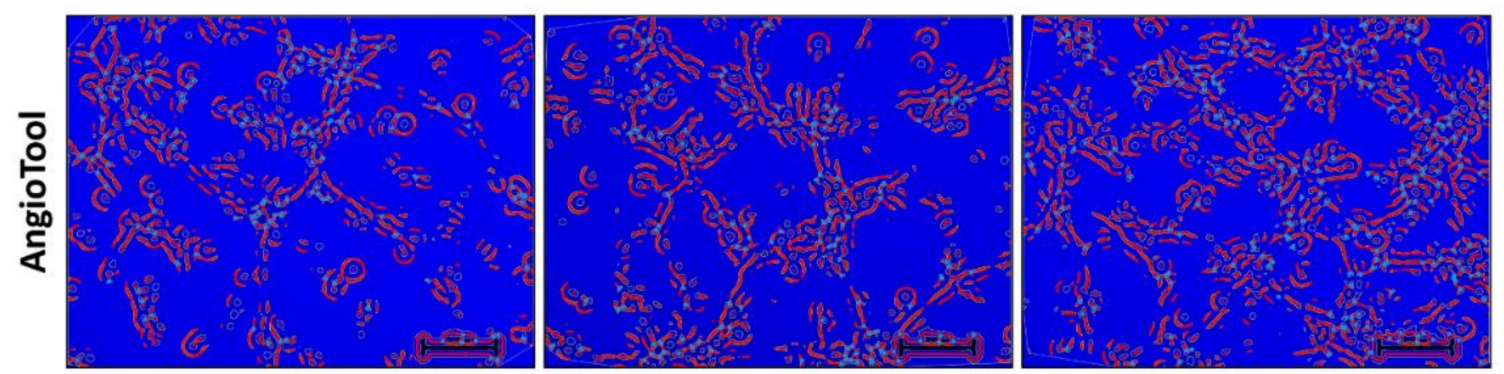

C

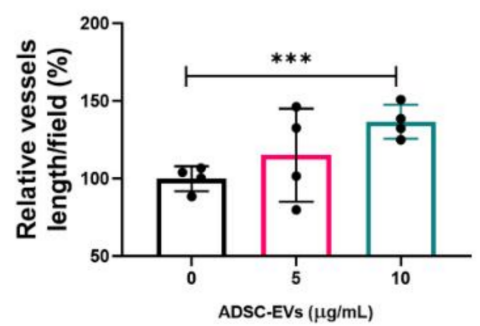

D

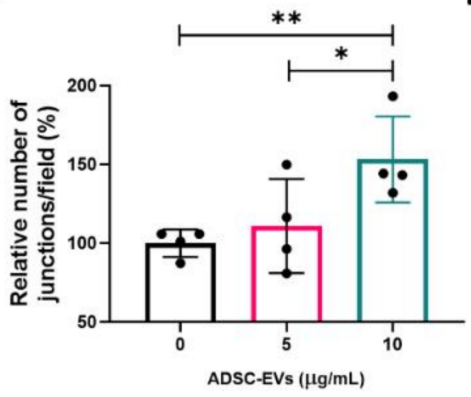

$\mathbf{E}$

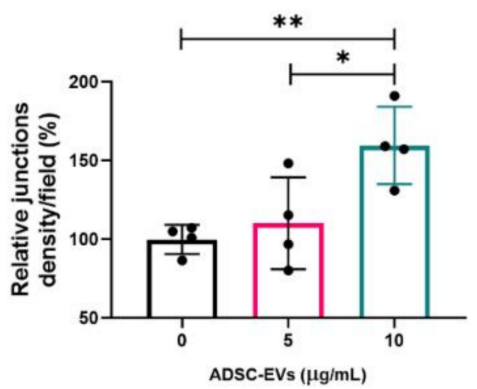

Figure 5. Treatment with ADSC-EVs promoted the in vitro tube-like formation of endothelial cells. (A) Representative phase contrast images showing endothelial cells cultured on Matrigel-coated plates in medium with ADSC-EVs (0, 5, or $10 \mu \mathrm{g} / \mathrm{mL}$ ) (scale bar: 200 pixels). (B) AngioTool64 software was used to analyse the images, and the vessels (red lines) and junctions (blue dots) are shown. (C-E) The relative total vessel length, number of junctions, and junction density were measured in the images $(n=4)$ using AngioTool64 software, Version $0.6 \mathrm{a}(02.18 .14) .{ }^{*} p<0.05,{ }^{* *} p<0.01,{ }^{* * *} p<0.001$ by Student's $t$-test.

\subsection{ADSC-EVs Promote Angiogenesis In Vivo}

After confirming the in vitro angiogenic effect (blood-vessel-like formation) of ADSCEVs, the in vivo angiogenic effect was tested in a mouse model. A schematic diagram of the in vivo Matrigel plug mouse model is presented in Figure 6A. Matrigel $(n=3)$ or Matrigel + ADSC-EVs $(n=4)$ was subcutaneously injected into mice. The Matrigel plugs were removed after 2 weeks and were visually examined and photographed using a surgical microscope. The Matrigel plugs of the Matrigel group showed minimal or no blood vessels, but the Matrigel plugs of the Matrigel + ADSC-EVs group showed blood vessels (upper panel; Figure 6B). Cross sections of the Matrigel plugs were stained with $\mathrm{H} \& \mathrm{E}$, and the results confirmed the presence of blood vessels in both groups (lower panel; Figure 6B). The number of blood vessels in the Matrigel plugs of the Matrigel + ADSC-EVs group was significantly greater than the number in the control $(p<0.001$ : per image field and $p<0.05$ per plug) (Figure 6C). These results confirm that ADSC-EVs are capable of inducing angiogenesis in vivo. 


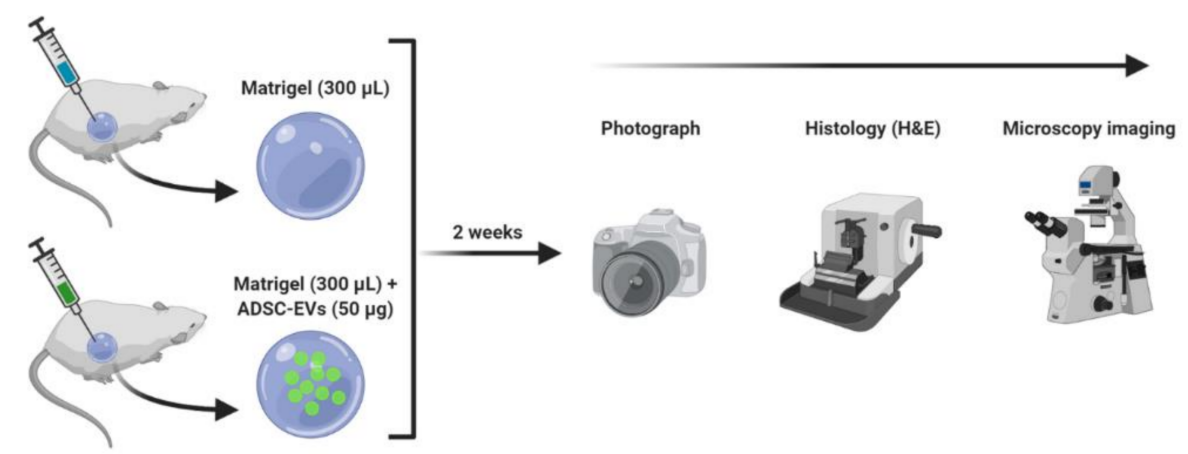

B
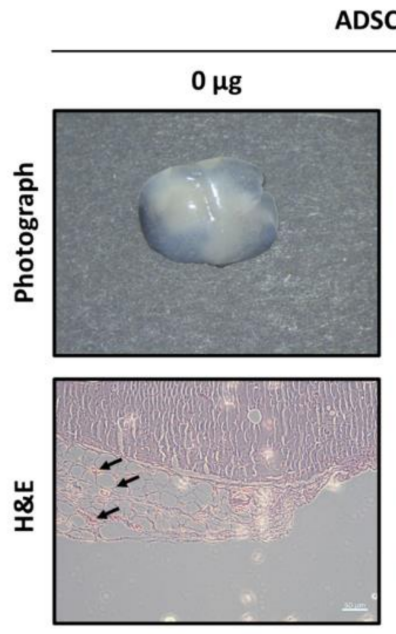

ADSC-EVs
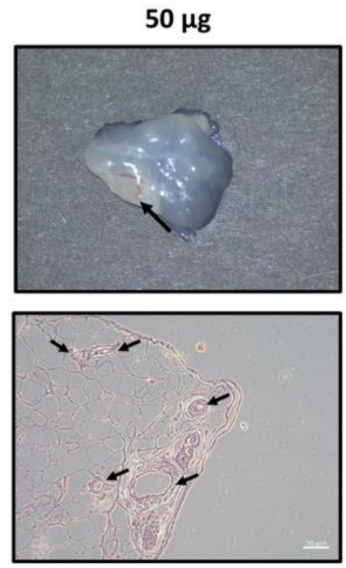

C

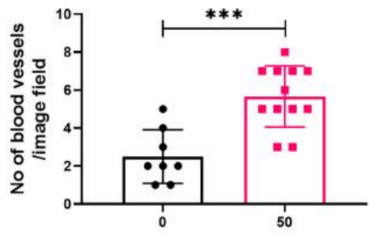

ADSC-EVs $(\mu \mathrm{g})$

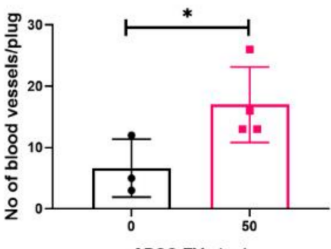

Figure 6. Treatment with ADSC-EVs increased the number of blood vessels in a Matrigel plug mouse model. (A) A schematic diagram of the in vivo Matrigel plug mouse model (figure created with BioRender.com). (B) Representative photograph and H\&E staining of the Matrigel plugs for the control and Matrigel + ADSC-EVs $(50 \mu \mathrm{g})$ groups; black arrows denote blood vessels (scale bar: $50 \mu \mathrm{m})$. (C) The number of blood vessels was counted from the images of H\&E staining. ${ }^{*} p<0.05$, $* * * p<0.001$ by Student's $t$-test.

\section{Discussion}

Angiogenesis is essential for recovery from ischaemic diseases. Stem-cell-derived EVs have recently emerged as a promising therapeutic candidate for numerous diseases [21,29,32,39], but the clinical translation of stem-cell-derived EVs has not yet been achieved. In this study, we aimed to isolate stem-cell-derived EVs with the potential to be used in clinical translation. To this end, we isolated stem cells from discarded adipose tissue after surgeries, the characteristics of which have been reported in our previous study [40].

ADSC-EVs were isolated and purified by ultracentrifugation of cell-free and filtered ADSC cultured media. The purification of primary ADSC-EVs was confirmed by the enrichment of the EV marker CD81, and the absence of the cell markers (GM130, calnexin, and cytochrome-C), and was further confirmed by their round shape in TEM images and their size range by NTA, which matches with other previously reported studies $[20,32,40,41]$.

Many previous studies have reported that stem-cell-derived EVs have angiogenic protein, and some studies showed angiogenic miRNAs [20,32]. The studies showing the presence of angiogenic proteins in EVs have mostly been focused on a solitary factor, despite the fact that EVs may contain numerous other angiogenic proteins. Therefore, in the current study, we investigated 20 angiogenic proteins in ADSC-EVs isolated from two 
human subjects. Angiogenic protein array revealed the presence of multiple angiogenic proteins in the ADSC-EVs, in agreement with previously reported studies [42-45]. Our results revealed that IL- 8 was present at a greater level compared with the other tested angiogenic proteins, while CCL2 was also present at a relatively high level in ADSCEVs; both of these have been reported to induce angiogenesis [46,47]. Indeed, a previous study on various cell types demonstrated that CCL2 and IL-8 were associated with the EV membrane more than 50\% [43]. Moreover, TIMP-1 and TIMP-2, known to inhibit angiogenesis, were also present in the ADSC-EVs, which is in agreement with previous studies showing that both TIMPs were secreted via EVs (bone marrow stem cells and cancer cells) [45,48-52]. VEGF-D, the strongest inducer of angiogenesis and lymphangiogenesis among VEGFs, was also present in high levels in ADSC-EVs [53-55].

EVs are well-known mediators of cell-to-cell communication as a result of their ability to deliver biological materials to recipient cells [25], and it is this property of EVs that has led scientists to exploit EVs as therapeutic agents and drug delivery vehicles [25,56]. Importantly, our results show that ADSC-EVs were internalised into endothelial cells. The migration and proliferation of endothelial cells is crucial for the initiation of angiogenesis from pre-existing vasculature [57]. The internalisation of ADSC-EVs caused endothelial cells to migrate more than untreated cells. Moreover, a previous study reported that IL-8 could induce angiogenesis by directly regulating the survival, proliferation, and migration of endothelial cells [46]. Another study showed that IL-8 promotes the proliferation of human intestinal microvascular endothelial cells and phosphorylation of ERK mediated by CXCR2 [47]. Furthermore, it was reported that CCL2 treatment increases the proliferation and migration of endothelial cells [58,59], and VEGF-D induces the proliferation and migration of endothelial cells, which is vital for angiogenesis [60]. Therefore, the high levels of IL-8, CCL2, and VEGF-D in ADSC-EVs may be responsible for the migration and proliferation of endothelial cells observed in our study.

During angiogenesis, and after the migration and proliferation of endothelial cells, blood vessel formation occurs under suitable conditions and in the presence of certain factors [57]. Therefore, to further investigate the angiogenic potential of ADSC-EVs, we examined the blood-vessel-like formation of endothelial cells in vitro. Our results showed that ADSC-EVs induced a more tube-like formation of endothelial cells compared with the control, which was confirmed by AngioTool analysis. The results showed an increased total vessel length, total number of junctions, and junction density. As mentioned previously, high levels of IL-8, CCL2, and VEGF-D may be responsible for the enhanced tube-like formation of endothelial cells $[46,47,53,54,58,59]$. Further, we performed the Matrigel plug assay in mice to confirm the in vivo angiogenic effect of ADSC-EVs in a preclinical mouse model. Our results showed that ADSC-EVs increased blood vessel formation in in vivo Matrigel plugs compared with the control material only. Furthermore, these results confirmed that ADSCs in the Matrigel effectively induced angiogenesis, which is in agreement with our previous study [61].

Other proteins, miRNA, or a combination of these may be involved in the induction of angiogenesis in endothelial cells in addition to the proangiogenic proteins reported in the current study. To the best of our knowledge, this study is the first to show the presence of IL-8, CCL2, and VEGF-D in stem-cell-derived EVs, as well as in ADSC-EVs. Although antiangiogenic TIMP-1 and TIMP-2 were present in the ADSC-EVs, they did not affect the promotion of angiogenesis. Although we have shown proangiogenic effects of ADSC-EVs in vitro and in vivo, further preclinical studies in ischaemic models are required to evaluate their clinical potential. Furthermore, the knockdown of proteins will also be important in unravelling the role of particular proteins in ADSC-EVs-mediated angiogenesis.

\section{Conclusions}

The results of the current study reveal the presence of proangiogenic proteins (IL-8, CCL2, and VEGF-D) in human primary ADSC-EVs, and also demonstrate the proangiogenic effect of ADSC-EVs in vitro and in vivo. These findings suggest that ADSC-EVs, 
which are feasibly isolated from adipose tissue, are a promising therapeutic for ischaemic diseases in the future.

Author Contributions: Conceptualization, P.G., R.L.R., H.Y.C., J.L. and B.-C.A.; Data curation, P.G., R.L.R. and J.M.O.; Formal analysis, P.G., R.L.R., J.M.O., E.J.O., C.M.H. and B.-C.A.; Funding acquisition, P.G., J.L. and B.-C.A.; Investigation, P.G., R.L.R., J.M.O., E.J.O. and H.Y.C.; Methodology, P.G., R.L.R., J.M.O., J.L. and B.-C.A.; Resources, E.J.O., C.M.H., H.Y.C., J.L. and B.-C.A.; Supervision, B.-C.A. All authors have read and agreed to the published version of the manuscript.

Funding: This research was supported by the Basic Science Research Program through the National Research Foundation of Korea (NRF), funded by the Ministry of Education (NRF-2019R1I1A1A01061296, NRF-2019R1I1A3A01063308). This research was supported by a grant from the Korea Health Technology R\&D Project through the Korea Health Industry Development Institute, funded by the Ministry of Health \& Welfare, Republic of Korea (HI15C0001).

Institutional Review Board Statement: This study was approved by the Institutional Review Board (IRB) of Kyungpook National University Hospital (IRB no. 2020-02-035-002) and was performed in accordance with the principles of the Declaration of Helsinki. All procedures were reviewed and approved by Kyungpook National University, Animal Care and Use Committee (KNU-20190121), and were performed in accordance with the Guiding Principles for the Care and Use of Laboratory Animals.

Informed Consent Statement: Informed consent was obtained from all the subjects involved in the study.

Data Availability Statement: Data will be made available upon reasonable request.

Conflicts of Interest: The authors declare no conflict of interest.

\section{References}

1. Kalogeris, T.; Baines, C.P.; Krenz, M.; Korthuis, R.J. Cell Biology of Ischemia/Reperfusion Injury. Int. Rev. Cell Mol. Biol. 2012, 298, 229-317. [CrossRef] [PubMed]

2. Secord, A.A.; Siamakpour-Reihani, S. Chapter 5-Angiogenesis. In Translational Advances in Gynecologic Cancers; Birrer, M.J., Ceppi, L., Eds.; Academic Press: Boston, FL, USA, 2017; pp. 79-109; ISBN 978-0-12-803741-6.

3. Tahergorabi, Z.; Khazaei, M. Imbalance of Angiogenesis in Diabetic Complications: The Mechanisms. Int. J. Prev. Med. 2012, 3, 827-838. [CrossRef] [PubMed]

4. Slattery, M.L.; John, E.M.; Torres-Mejia, G.; Lundgreen, A.; Lewinger, J.P.; Stern, M.; Hines, L.; Baumgartner, K.B.; Giuliano, A.R.; Wolff, R.K. Angiogenesis Genes, Dietary Oxidative Balance, and Breast Cancer Risk and Progression: The Breast Cancer Health Disparities Study. Int. J. Cancer 2014, 134, 629-644. [CrossRef] [PubMed]

5. Balasubramanian, S.P.; Brown, N.J.; Reed, M.W.R. Role of Genetic Polymorphisms in Tumour Angiogenesis. Br. J. Cancer 2002, 87, 1057-1065. [CrossRef]

6. WHO. Disease Burden and Mortality Estimates. Available online: http://www.who.int/healthinfo/global_burden_disease/ estimates/en/ (accessed on 25 February 2021).

7. Johnson, C.O.; Nguyen, M.; Roth, G.A.; Nichols, E.; Alam, T.; Abate, D.; Abd-Allah, F.; Abdelalim, A.; Abraha, H.N.; Abu-Rmeileh, N.M.; et al. Global, Regional, and National Burden of Stroke, 1990-2016: A Systematic Analysis for the Global Burden of Disease Study 2016. Lancet Neurol. 2019, 18, 439-458. [CrossRef]

8. Sawant, S.S.; Vaidya, M.M.; Chaukar, D.A.; Alam, H.; Dmello, C.; Gangadaran, P.; Kannan, S.; Kane, S.; Dange, P.P.; Dey, N.; et al. Clinical Significance of Aberrant Vimentin Expression in Oral Premalignant Lesions and Carcinomas. Oral Dis. 2014, 20, 453-465. [CrossRef]

9. Zhang, S.; Lachance, B.B.; Moiz, B.; Jia, X. Optimizing Stem Cell Therapy after Ischemic Brain Injury. J. Stroke 2020, 22, 286-305. [CrossRef]

10. Michler, R.E. The Current Status of Stem Cell Therapy in Ischemic Heart Disease. J. Card. Surg. 2018, 33, 520-531. [CrossRef]

11. Wang, Y.; Xu, F.; Ma, J.; Shi, J.; Chen, S.; Liu, Z.; Liu, J. Effect of Stem Cell Transplantation on Patients with Ischemic Heart Failure: A Systematic Review and Meta-Analysis of Randomized Controlled Trials. Stem Cell Res. Ther. 2019, 10, 125. [CrossRef]

12. Yu, H.; Lu, K.; Zhu, J.; Wang, J. Stem Cell Therapy for Ischemic Heart Diseases. Br. Med. Bull. 2017, 121, 135-154. [CrossRef]

13. MacAskill, M.G.; Saif, J.; Condie, A.; Jansen, M.A.; MacGillivray, T.J.; Tavares, A.A.S.; Fleisinger, L.; Spencer, H.L.; Besnier, M.; Martin, E.; et al. Robust Revascularization in Models of Limb Ischemia Using a Clinically Translatable Human Stem Cell-Derived Endothelial Cell Product. Mol. Ther. 2018, 26, 1669-1684. [CrossRef]

14. Kanji, S.; Das, H. Advances of Stem Cell Therapeutics in Cutaneous Wound Healing and Regeneration. Mediat. Inflamm. 2017, 2017. [CrossRef] 
15. Wang, C.-H.; Cherng, W.-J.; Verma, S. Drawbacks to Stem Cell Therapy in Cardiovascular Diseases. Future Cardiol. 2008, 4, 399-408. [CrossRef]

16. Sun, Q.; Zhang, Z.; Sun, Z. The Potential and Challenges of Using Stem Cells for Cardiovascular Repair and Regeneration. Genes Dis. 2014, 1, 113-119. [CrossRef]

17. Gorecka, J.; Kostiuk, V.; Fereydooni, A.; Gonzalez, L.; Luo, J.; Dash, B.; Isaji, T.; Ono, S.; Liu, S.; Lee, S.R.; et al. The Potential and Limitations of Induced Pluripotent Stem Cells to Achieve Wound Healing. Stem Cell Res. Ther. 2019, 10, 87. [CrossRef]

18. Lukomska, B.; Stanaszek, L.; Zuba-Surma, E.; Legosz, P.; Sarzynska, S.; Drela, K. Challenges and Controversies in Human Mesenchymal Stem Cell Therapy. Stem Cells Int. 2019, 2019, 9628536. [CrossRef]

19. Zakrzewski, W.; Dobrzyński, M.; Szymonowicz, M.; Rybak, Z. Stem Cells: Past, Present, and Future. Stem Cell Res. Ther. 2019, 10, 68. [CrossRef]

20. Gangadaran, P.; Rajendran, R.L.; Lee, H.W.; Kalimuthu, S.; Hong, C.M.; Jeong, S.Y.; Lee, S.-W.; Lee, J.; Ahn, B.-C. Extracellular Vesicles from Mesenchymal Stem Cells Activates VEGF Receptors and Accelerates Recovery of Hindlimb Ischemia. J. Control. Release Off. J. Control. Release Soc. 2017, 264, 112-126. [CrossRef]

21. Rajendran, R.L.; Gangadaran, P.; Bak, S.S.; Oh, J.M.; Kalimuthu, S.; Lee, H.W.; Baek, S.H.; Zhu, L.; Sung, Y.K.; Jeong, S.Y.; et al. Extracellular Vesicles Derived from MSCs Activates Dermal Papilla Cell in Vitro and Promotes Hair Follicle Conversion from Telogen to Anagen in Mice. Sci. Rep. 2017, 7, 15560. [CrossRef]

22. Oh, E.J.; Gangadaran, P.; Rajendran, R.L.; Kim, H.M.; Oh, J.M.; Choi, K.Y.; Chung, H.Y.; Ahn, B.-C. Extracellular Vesicles Derived from Fibroblasts Promote Wound Healing by Optimizing Fibroblast and Endothelial Cellular Functions. Stem Cells Dayt. Ohio 2020. [CrossRef]

23. Hu, G.; Li, Q.; Niu, X.; Hu, B.; Liu, J.; Zhou, S.; Guo, S.; Lang, H.; Zhang, C.; Wang, Y.; et al. Exosomes Secreted by Human-Induced Pluripotent Stem Cell-Derived Mesenchymal Stem Cells Attenuate Limb Ischemia by Promoting Angiogenesis in Mice. Stem Cell Res. Ther. 2015, 6, 10. [CrossRef] [PubMed]

24. Zhang, K.; Zhao, X.; Chen, X.; Wei, Y.; Du, W.; Wang, Y.; Liu, L.; Zhao, W.; Han, Z.; Kong, D.; et al. Enhanced Therapeutic Effects of Mesenchymal Stem Cell-Derived Exosomes with an Injectable Hydrogel for Hindlimb Ischemia Treatment. ACS Appl. Mater. Interfaces 2018, 10, 30081-30091. [CrossRef] [PubMed]

25. Gangadaran, P.; Ahn, B.-C. Extracellular Vesicle- and Extracellular Vesicle Mimetics-Based Drug Delivery Systems: New Perspectives, Challenges, and Clinical Developments. Pharmaceutics 2020, 12, 442. [CrossRef] [PubMed]

26. Doyle, L.M.; Wang, M.Z. Overview of Extracellular Vesicles, Their Origin, Composition, Purpose, and Methods for Exosome Isolation and Analysis. Cells 2019, 8, 727. [CrossRef]

27. Huang, Y.-Z.; Gou, M.; Da, L.-C.; Zhang, W.-Q.; Xie, H.-Q. Mesenchymal Stem Cells for Chronic Wound Healing: Current Status of Preclinical and Clinical Studies. Tissue Eng. Part B Rev. 2020, 26, 555-570. [CrossRef]

28. Lai, R.C.; Arslan, F.; Lee, M.M.; Sze, N.S.K.; Choo, A.; Chen, T.S.; Salto-Tellez, M.; Timmers, L.; Lee, C.N.; El Oakley, R.M.; et al. Exosome Secreted by MSC Reduces Myocardial Ischemia/Reperfusion Injury. Stem Cell Res. 2010, 4, 214-222. [CrossRef]

29. Shabbir, A.; Cox, A.; Rodriguez-Menocal, L.; Salgado, M.; Van Badiavas, E. Mesenchymal Stem Cell Exosomes Induce Proliferation and Migration of Normal and Chronic Wound Fibroblasts, and Enhance Angiogenesis In Vitro. Stem Cells Dev. 2015, 24, $1635-1647$. [CrossRef]

30. De Mayo, T.; Conget, P.; Becerra-Bayona, S.; Sossa, C.L.; Galvis, V.; Arango-Rodríguez, M.L. The Role of Bone Marrow Mesenchymal Stromal Cell Derivatives in Skin Wound Healing in Diabetic Mice. PLoS ONE 2017, 12, e0177533. [CrossRef]

31. Li, X.; Liu, L.; Yang, J.; Yu, Y.; Chai, J.; Wang, L.; Ma, L.; Yin, H. Exosome Derived From Human Umbilical Cord Mesenchymal Stem Cell Mediates MiR-181c Attenuating Burn-Induced Excessive Inflammation. EBioMedicine 2016, 8, 72-82. [CrossRef]

32. Zhu, Y.; Zhang, J.; Hu, X.; Wang, Z.; Wu, S.; Yi, Y. Extracellular Vesicles Derived from Human Adipose-Derived Stem Cells Promote the Exogenous Angiogenesis of Fat Grafts via the Let-7/AGO1/VEGF Signalling Pathway. Sci. Rep. 2020, 10, 5313. [CrossRef]

33. Maumus, M.; Rozier, P.; Boulestreau, J.; Jorgensen, C.; Noël, D. Mesenchymal Stem Cell-Derived Extracellular Vesicles: Opportunities and Challenges for Clinical Translation. Front. Bioeng. Biotechnol. 2020, 8. [CrossRef]

34. Ramakrishnan, A.; Torok-Storb, B.; Pillai, M.M. Primary Marrow-Derived Stromal Cells: Isolation and Manipulation. In Stem Cell Niche: Methods and Protocols; Turksen, K., Ed.; Methods in Molecular Biology; Humana Press: Totowa, NJ, USA, 2013; pp. 75-101; ISBN 978-1-62703-508-8.

35. Fraser, J.K.; Wulur, I.; Alfonso, Z.; Hedrick, M.H. Fat Tissue: An Underappreciated Source of Stem Cells for Biotechnology. Trends Biotechnol. 2006, 24, 150-154. [CrossRef]

36. Lee, J.W.; Chu, S.G.; Kim, H.T.; Choi, K.Y.; Oh, E.J.; Shim, J.-H.; Yun, W.-S.; Huh, J.B.; Moon, S.H.; Kang, S.S.; et al. Osteogenesis of Adipose-Derived and Bone Marrow Stem Cells with Polycaprolactone/Tricalcium Phosphate and Three-Dimensional Printing Technology in a Dog Model of Maxillary Bone Defects. Polymers 2017, 9, 450. [CrossRef]

37. Justus, C.R.; Leffler, N.; Ruiz-Echevarria, M.; Yang, L.V. In Vitro Cell Migration and Invasion Assays. J. Vis. Exp. 2014. [CrossRef]

38. Zudaire, E.; Gambardella, L.; Kurcz, C.; Vermeren, S. A Computational Tool for Quantitative Analysis of Vascular Networks. PLoS ONE 2011, 6, e27385. [CrossRef]

39. Wu, S.; Ju, G.-Q.; Du, T.; Zhu, Y.-J.; Liu, G.-H. Microvesicles Derived from Human Umbilical Cord Wharton's Jelly Mesenchymal Stem Cells Attenuate Bladder Tumor Cell Growth In Vitro and In Vivo. PLoS ONE 2013, 8, e61366. [CrossRef] 
40. Rajendran, R.L.; Paudel, S.; Gangadaran, P.; Oh, J.M.; Oh, E.J.; Hong, C.M.; Lee, S.; Chung, H.Y.; Lee, J.; Ahn, B.-C. Extracellular Vesicles Act as Nano-Transporters of Tyrosine Kinase Inhibitors to Revert Iodine Avidity in Thyroid Cancer. Pharmaceutics 2021, 13, 248. [CrossRef]

41. Rajendran, R.L.; Gangadaran, P.; Seo, C.H.; Kwack, M.H.; Oh, J.M.; Lee, H.W.; Gopal, A.; Sung, Y.K.; Jeong, S.Y.; Lee, S.-W.; et al. Macrophage-Derived Extracellular Vesicle Promotes Hair Growth. Cells 2020, 9, 856. [CrossRef]

42. Barnes, B.J.; Somerville, C.C. Modulating Cytokine Production via Select Packaging and Secretion From Extracellular Vesicles. Front. Immunol. 2020, 11. [CrossRef]

43. Fitzgerald, W.; Freeman, M.L.; Lederman, M.M.; Vasilieva, E.; Romero, R.; Margolis, L. A System of Cytokines Encapsulated in ExtraCellular Vesicles. Sci. Rep. 2018, 8, 8973. [CrossRef]

44. Kuravi, S.J.; Harrison, P.; Rainger, G.E.; Nash, G.B. Ability of Platelet-Derived Extracellular Vesicles to Promote NeutrophilEndothelial Cell Interactions. Inflammation 2019, 42, 290-305. [CrossRef]

45. Shimoda, M.; Khokha, R. Metalloproteinases in Extracellular Vesicles. Biochim. Biophys. Acta Mol. Cell Res. 2017, 1864, 1989-2000. [CrossRef]

46. Li, A.; Dubey, S.; Varney, M.L.; Dave, B.J.; Singh, R.K. IL-8 Directly Enhanced Endothelial Cell Survival, Proliferation, and Matrix Metalloproteinases Production and Regulated Angiogenesis. J. Immunol. 2003, 170, 3369-3376. [CrossRef]

47. Heidemann, J.; Ogawa, H.; Dwinell, M.B.; Rafiee, P.; Maaser, C.; Gockel, H.R.; Otterson, M.F.; Ota, D.M.; Lügering, N.; Domschke, W.; et al. Angiogenic Effects of Interleukin 8 (CXCL8) in Human Intestinal Microvascular Endothelial Cells Are Mediated by CXCR2. J. Biol. Chem. 2003, 278, 8508-8515. [CrossRef]

48. Vallabhaneni, K.C.; Penfornis, P.; Dhule, S.; Guillonneau, F.; Adams, K.V.; Mo, Y.Y.; Xu, R.; Liu, Y.; Watabe, K.; Vemuri, M.C.; et al. Extracellular Vesicles from Bone Marrow Mesenchymal Stem/Stromal Cells Transport Tumor Regulatory MicroRNA, Proteins, and Metabolites. Oncotarget 2014, 6, 4953-4967. [CrossRef]

49. Demory Beckler, M.; Higginbotham, J.N.; Franklin, J.L.; Ham, A.-J.; Halvey, P.J.; Imasuen, I.E.; Whitwell, C.; Li, M.; Liebler, D.C.; Coffey, R.J. Proteomic Analysis of Exosomes from Mutant KRAS Colon Cancer Cells Identifies Intercellular Transfer of Mutant KRAS. Mol. Cell. Proteom. 2013, 12, 343-355. [CrossRef]

50. Chan, Y.-K.; Zhang, H.; Liu, P.; Tsao, S.-W.; Lung, M.L.; Mak, N.-K.; Wong, R.N.-S.; Yue, P.Y.-K. Proteomic Analysis of Exosomes from Nasopharyngeal Carcinoma Cell Identifies Intercellular Transfer of Angiogenic Proteins. Int. J. Cancer 2015, 137, 1830-1841. [CrossRef]

51. Minciacchi, V.R.; You, S.; Spinelli, C.; Morley, S.; Zandian, M.; Aspuria, P.-J.; Cavallini, L.; Ciardiello, C.; Sobreiro, M.R.; Morello, M.; et al. Large Oncosomes Contain Distinct Protein Cargo and Represent a Separate Functional Class of Tumor-Derived Extracellular Vesicles. Oncotarget 2015, 6, 11327-11341. [CrossRef]

52. Quintero-Fabián, S.; Arreola, R.; Becerril-Villanueva, E.; Torres-Romero, J.C.; Arana-Argáez, V.; Lara-Riegos, J.; Ramírez-Camacho, M.A.; Alvarez-Sánchez, M.E. Role of Matrix Metalloproteinases in Angiogenesis and Cancer. Front. Oncol. 2019, 9. [CrossRef]

53. Rissanen, T.T.; Markkanen, J.E.; Gruchala, M.; Heikura, T.; Puranen, A.; Kettunen, M.I.; Kholová, I.; Kauppinen, R.A.; Achen, M.G.; Stacker, S.A.; et al. VEGF-D Is the Strongest Angiogenic and Lymphangiogenic Effector Among VEGFs Delivered Into Skeletal Muscle via Adenoviruses. Circ. Res. 2003, 92, 1098-1106. [CrossRef]

54. Bower, N.I.; Vogrin, A.J.; Guen, L.L.; Chen, H.; Stacker, S.A.; Achen, M.G.; Hogan, B.M. Vegfd Modulates Both Angiogenesis and Lymphangiogenesis during Zebrafish Embryonic Development. Development 2017, 144, 507-518. [CrossRef] [PubMed]

55. Roy, H.; Bhardwaj, S.; Ylä-Herttuala, S. Biology of Vascular Endothelial Growth Factors. FEBS Lett. 2006, 580, $2879-2887$. [CrossRef] [PubMed]

56. Gangadaran, P.; Hong, C.M.; Ahn, B.-C. An Update on in Vivo Imaging of Extracellular Vesicles as Drug Delivery Vehicles. Front. Pharmacol. 2018, 9, 169. [CrossRef] [PubMed]

57. Senger, D.R.; Davis, G.E. Angiogenesis. Cold Spring Harb. Perspect. Biol. 2011, 3. [CrossRef]

58. Ma, J.; Wang, Q.; Fei, T.; Han, J.-D.J.; Chen, Y.-G. MCP-1 Mediates TGF- $\beta$-Induced Angiogenesis by Stimulating Vascular Smooth Muscle Cell Migration. Blood 2006, 109, 987-994. [CrossRef]

59. Hong, K.H.; Ryu, J.; Han, K.H. Monocyte Chemoattractant Protein-1-Induced Angiogenesis Is Mediated by Vascular Endothelial Growth Factor-A. Blood 2005, 105, 1405-1407. [CrossRef]

60. Lamalice, L.; Le Boeuf, F.; Huot, J. Endothelial Cell Migration During Angiogenesis. Circ. Res. 2007, 100, 782-794. [CrossRef]

61. Gangadaran, P.; Rajendran, R.L.; Oh, J.M.; Hong, C.M.; Jeong, S.Y.; Lee, S.-W.; Lee, J.; Ahn, B.-C. Extracellular Vesicles Derived from Macrophage Promote Angiogenesis In Vitro and Accelerate New Vasculature Formation In Vivo. Exp. Cell Res. 2020, 394, 112146. [CrossRef] 